Article Type: Research Paper

\title{
Financial Sector Performance: Evidence in Twelve West African Countries
}

\author{
Ibrahim Sorie Kamara ${ }^{1 *}$, Siti Aisyah Tri Rahayu², and Lukman Hakim³
}

\section{O OPEN}

\section{AFFILIATION:}

1, 2, 3 Department of Economics, Faculty of Economics and Business, Universitas Sebelas Maret, Surakarta, Indonesia.

*CORRESPONDENCE:

ibrahimsoriekamara216@gmail.com

THIS ARTICLE IS AVALILABLE IN:

http://journal.umy.ac.id/index.php/esp

DOI: 10.18196/jesp.21.2.5041

\section{CITATION:}

Kamara, I. S., Rahayu, S. A. T., \& Hakim, L. (2020). Financial Sector Performance: Evidence in Twelve West African Countries. Jurnal Ekonomi \& Studi Pembangunan, 21(2), 199-207.

\section{ARTICLE HISTORY}

Received:

11 June 2020

Reviewed:

29 June 2020

10 Oct 2020

Revised:

08 Aug 2020

16 Oct 2020

Accepted:

16 Oct 2020
Abstract: In most West African countries, the financial sectors are the least developed area. The absence of deep-efficient financial markets put major economic growth constraints. This study aimed to investigate the financial sector performance in twelve selected West African countries. To determine financial sector performance, a panel data semi-log model was employed. Data were collected from the World Bank Open data page from 2004-2013. The results revealed that both variables matched the hypothesis, indicating a positive impact in the financial sector. It indicated that the variables used in this study were major players of the financial sector in the selected countries. This study recommends that because financial stability, globally and within countries, generates jobs and improves productivity, more efforts should be made to ensure an effective and developed financial sector system. It is so because limited and inadequate access to credit will limit small and medium-sized enterprises' contributions to private sector development.

Keywords: Financial Sector Performance; Economic Growth; West Africa JEL Classification: G19; 040

\section{Introduction}

The financial sector of any country is rarely mentioned as one of the major areas of improvement for its overall development (de Soto, 2006). In fact, simple transactions, such as bill payments that are due, occur probably through the financial sector. Another, more complex transaction, which is crucial for business transactions and investments, also takes place through the financial sector. It is the stage where the financial sector development can have the greatest impact on economic growth (Levine, 1997). Evidenced by the events in 2008 after the crash of the financial markets worldwide and the added threat of much more distress, it gave national governments the motivation to act. They provided buyouts larger than ever previously seen to prevent additional disasters in the financial markets that could show spillover effects over their domestic economies and trading partners' economies (Ivashina \& Scharfstein, 2010). These governments' actions reflected that the financial sector should not be ignored as it can undoubtedly impact a country's economy. The financial sector's development can assist in impeding its limitation to negatively affect their domestic economies. 
Thus, the importance of developed countries' financial sector for their economies is evident as they experienced a recession in the periods after the global financial crisis (Cecchetti \& Kharroubi, 2015).

Moreover, there are understandable differences between developing and developed economies. It is interesting to assess whether these differences also account for the relationship between financial sector development and economic growth. The developing countries, which we chose to focus on, are located in West Africa. This particular group of countries has experienced a continued increase in their economies' growth in the last decade. It resulted from better policies aimed at improving sound macroeconomic conditions and positive external conditions, which were the surrounding markets (Sosa \& Marle, 2013). According to (Didier \& Schmukler, 2013), the financial sector in West African countries has improved considerably. However, it is interesting to know whether the financial sector has an added value related to their economies' growth. The theory regarding the relationship between economic growth and financial development has its foundation from the main functions of the financial sector's influence on capital accumulation and technology development. The financial sector development is considered an improvement of its primary functions or, additionally, the reduction of barriers set by national governments that negatively impact the number of transactions conducted in the economy (Balassa, 1990).

Because of these controversial debates, it is interesting to investigate whether the financial sector can influence economic growth. There is a need to find development regulations and macroeconomic policies that will enhance growth. This study examines the financial sector performance using a panel data analysis of twelve selected subSaharan African countries (Sierra Leone, Liberia, Ghana, Nigeria, Gambia, Senegal, Ivory Coast, Mauritania, Burkina Faso, Cape Verde, Guinea, and Mali). The choice of these developing countries is based on the fact that their economies have an average level of financial development because of their socio-economic, political, and institutional history (Akinlo \& Egbetunde, 2010). Until the reform implementation in most sub-Saharan African countries in the mid-1980s, commercial banks have dominated the banking system. Due to the low development level of stock and bond markets in sub-Saharan Africa, banks play a crucial intermediary role and represent the primary source of companies' external capital (World Bank, 2016). On the contrary, progress is made in financial sector performance even though there remains considerable scope for further developments. It was partly a result of improvements in finance's institutional framework, such as establishing commercial courts and alternative dispute resolution systems, credit reference bureaus, and macroeconomic stability (Beck, Brumbaugh, Airoldi, Carranza, Coen, Crawford, Defeo, Edgar, Hancock, Kay, Lenihan, Luckenbach, Toropova, Zhang, \& Guo, 2011).

This paper aims is to verify the financial sector performance empirically in the context of 12 Sub-Saharan African (SSA) countries for the period 2004-2013. In detail, this study's objectives are twofold. The first is to determine whether SSA countries should seek ways to maximize the benefits of financial sector performance development while minimizing their costs. The second is to underline the fact that the financial sector can contribute to 
providing financial development with a predominant place in these countries' development policies.

The first part of this paper presents the background and empirical foundations of the nature of financial development and economic growth, and then the second part exposes an overview of financial developments. After that, the third part is the research method, and the fourth part is the results and the interpretations that result from these foundations.

The financial system's primary function is to enable resources' allocation through space and time in an uncertain environment. Financial sector development is defined as the process of strengthening and diversifying financial services' provision to meet economic growth requirements effectively and efficiently, thereby supporting and stimulating economic growth (Mongali, 2014). The financial systems may influence savings rate, investment decisions, technological innovation, and, ultimately, long-run economic growth (Levine, 2004). On the one hand, according to Soltani, Haghighat, Fanaei, and Asghari (2014), the robustness of the information asymmetry, which characterizes financial markets, maybe at the origin of a failure in coordinating the allocation of savings to investment. This information asymmetry may deform investors' anticipations who prefer to invest in a less risky environment than in an uncertain and riskier environment. They do this by taking into account the degree of investor risk aversion, financial market imperfections, and the high level of transaction costs. These difficulties in the financial market and this ineffective intermediation can only slow down economic growth. Furthermore, from the point of view of facts, the recent banking insolvency crises have thrown the economies into recessionary periods. This experience has given us an example of the negative impact of banking sector development on macroeconomic performance. These banking problems may transform themselves into banking or financial crises that can incur enormous costs for the whole economy.

The most famous works, which marked current affairs, are King and Levine (1993). These authors showed the vital role of the banking system and the financial market in economic growth development. They found a correlation between GDP (as an indicator of growth) and the financial system's size. Beck, Demirguc-Kunt, Levine, and Maksimovic (2000) also proved that the development of the banking system and the financial markets might lead to economic growth, provided a few conditions are respected. It has to do with the financial system's smooth functioning, weak information asymmetry, low transaction cost, and optimal resource allocation. Besides, Vazakidis and Adamopoulos (2009), in their joint works on developing the financial market and economic development, uncovered that the financial market's smooth functioning might favor growth. Similarly, in China's context, Shan and Qi (2006) argued that the contribution of financial development to economic growth is interpreted as the second force after the contribution of the workers' incomes. According to the authors, the link between the financial sphere and the economic sphere has a double sense of causality. The financial system development related to developing a banking credit distribution system to finance investments provides nominal GDP growth. They also argue that the strong economic growth registered in recent years has significantly impacted the financial system's development. 


\section{Composition of 12 Selected West African Financial Sectors}

Four vital components of a financial system consist of financial institutions, financial markets, regulatory authorities, and financial instruments. However, the financial system in West Africa has undergone some remarkable changes in terms of the following ownership structure, the depth and breadth of instruments employed, the number of institutions established, the economic environment, and the regulatory framework within which the system operates currently. West Africa's financial system includes banks, capital markets, insurance, pension asset managers, and other financial institutions, with the central bank as the apex institution.

\section{The Banking Subsector}

The banking subsector comprises deposit money banks, microfinance banks, primary mortgage institutions, trustees, and trust companies. In West Africa, commercial banks (deposit money) are the dominant operators in the industries. They are the largest in terms of size and profitability. Besides, microfinance is a financial institution established to provide credit, banking, and other financial services to designated convenient areas or communities. Microfinance banks are founded to provide financial access to the poor, who are traditionally not served by conventional financial institutions. It is because the formal financial system provides services to approximately 20 percent of the economically active population, while the eighty (80) percent are excluded from access to financial services (CBN, 2008). Moreover, primary mortgage institutions, also known as savings and loan companies, are specialized institutions that collect household savings and originate mortgage loans. There are currently many primary mortgage institutions in Nigeria. Meanwhile, trustees and trust companies are typically subsiding by banks. They provide funds and management services for organizations or individuals who set up trust funds. Other services include portfolio management, investment advising, property management, and custodial services for non-pension funds.

\section{Insurance Industry}

Insurance companies represent the second largest sector in the West Africa financial services industry. There are over thousands of insurance companies operating in West Africa. The minimum capital requirements to start an insurance company are 2 billion for life insurance companies and 8 billion for companies that provide non-life insurance, depending on the country's terms and conditions. Insurance brokers also fall under this group. These companies are registered with the National Insurance Corporation of each country. In some of these countries, only a few controls a significant proportion of life and license premium income of the industry. Like in Nigeria, there are also reassurance companies within the insurance industry. There are currently five reassurance companies in Nigeria. In September 2005, the Federal Ministry of Finance and NICON increased the minimum capital base for reassurance business in Nigeria to N10 billion starting from February 2007. Insurance agents are representatives of insurance companies on commission. 


\section{Capital Market}

A capital market serves as a network of financial institutions and infrastructure that mobilizes and allocates long-term funds in the economy. The capital market affords business firms and government the opportunity to sell stocks and bonds to raise longterm funds from other economic agents' savings. According to the Harrod-Domar model, the sourcing of long-term funds through the capital market is essential for self-sustained economic growth. A well-functioning capital market aids the mobilization of savings for economic growth and development. The capital market encourages the efficient allocation of resources through changes in wealth ownership. In this regard, the capital market acts as a catalyst in creating a healthy private sector and facilitates the promotion of rapid capital formation. There are issuing houses within the capital market that provide residual banking services and act as intermediaries in capital market activities. They operate between the company whose shares are being sold, the regulatory authorities, and the public. Issuing houses are registered with the Securities and Exchange Commission (SEC). Many of the issuing houses in West Africa are affiliates of banks. In West Africa, stockbrokers are also involved in capital market activities. For instance, there are 581 licensed stockbrokers in Nigeria.

\section{Other Financial Institutions}

Other financial institutions refer to discount houses, finance companies, bureau de change, and development of financial institutions and pension fund agencies in West Africa. Many of the private equity firms are offshoots of foreign firms. Discount houses specialize in trading money market securities with the specific purpose of providing liquidity and play market-making roles for short term market instruments. Meanwhile, the bureau is a company that carries out foreign exchange business on a small-scale basis. Then, Development Finance Institutions (DFTs) are usually government-owned financial institutions established to finance particular government developmental programs, usually in agriculture, commerce, manufacturing, industrial sectors, and others.

\section{Pension Fund Managers}

The pension fund managers were established for employees in West Africa as a contributory pension scheme for payment of employees' retirement benefits to whom the scheme applies. Under this Act, all employees in the public service of the Federation and the private sector are involved, as well as the judges and top political officeholders. The public service operates a defended and defined benefits scheme, and the payment of retirement benefits is budgeted annually. The annual budgetary allocation for pension is often one of the most important parts of the budget implementation in the light of resource constraints.

This study supports the above references of Mongali (2014) and Beck et al. (2000), stating that the financial sector performance is viable in these twelve West African countries. In other words, this study also gives similar results to previous research supporting the 
motion that financial sector performance plays a crucial role in developing the economy of any nation.

\section{Research Method}

\section{Data Collection}

The study's model consisted of four variables, with secondary yearly time series data. The variables were Gross Domestic Product (GDP), Exchange Rate (ER), Interest Rate (IR), Trade Openness (TO), and financial development (FD). The data for these variables were sourced from the World Bank Databank for the period 2004-2013. Specific countries were selected for this study based on the data available. The countries were Sierra Leone, Liberia, Ghana, Nigeria, Gambia, Senegal, Ivory Coast, Mauritania, Burkina Faso, Cape Verde, Guinea, and Mali. The estimated model comprised time series $i$ and cross-sectional t panel case.

\section{Model Specification}

To achieve the financial sector performance's aim in West Africa, the study referred to some works by Cecchetti and Kharroubi (2012), Beck et al. (2011), Obradovic, Sapic, Furtula, and Lojanica (2017), and others, which were discussed in the literature review section. Panel data was employed in this study with a semi-log model. The following equation was used in the form of semi-log format and is illustrated as follows,

$$
\log F D_{i t}=\beta_{0}+\beta_{11} \log I R_{i t}+\beta_{12} E R_{i t}+\beta_{13} T O_{i t}+\beta_{14} \log G D P_{i t}+\varepsilon_{i t}
$$

Where, financial development is the ratio of private credit to gross domestic product. Financial development (FD) was utilized as a proxy of the dependent variable for the 12 selected West African countries in this study, while the other variables were independent variables, such as interest rate (IR), the exchange rate (ER), gross domestic product (GDP) and trade openness (TO).

\section{Result and Discussion}

Table 1 The estimation result of the independent variables' effects on the financial development in the 12 selected countries in West Africa

Table 1 reveals the fixed-effects model results. Both variables matched the hypothesis, indicating a positive impact in the financial development, except for the interest rate that showed negative value. The R-squared displayed a value of $(0.902818)$, indicating that the variables used in this study were the major players in the financial sector. It also implied that a 90,28\% variation of the independent variables could explain variation in the dependent variable (financial development). The F-statistics had a significant value of (56.35929). Besides, the DW statistic had a value of (1.229386). All the variables indicate 
significant values with the exception of interest. Below is a detailed explanation of the four variables.

Table 1 The dependent variable is financial development

\begin{tabular}{lll}
\hline Independent Variables & Coefficient & t-statistics \\
\hline C & $-51.83036^{* * *}$ & -4.097947 \\
Log(IR) & $-1.888509^{* * *}$ & -5.408610 \\
Log(GDP) & $2.299737^{* * *}$ & 3.887833 \\
ER & $0.009741^{* * *}$ & 2.736512 \\
TO & $0.009813^{* * *}$ & 4.245977 \\
R-squared & & 0.902818 \\
F-statistic & & 56.35929 \\
Durbin-Watson statistic & 1.229386 \\
\hline
\end{tabular}

Note: ${ }^{*}, * *$ and ${ }^{* * *}$ explain $10 \%, 5 \%$ and $1 \%$ significant level respectively

\section{Gross Domestic Product}

Based on the analysis of the data in this study the results of the analysis show that the level of GDP has a significant positive effect on the financial sector development with a probability value of $0.0004<0.05$. The results of this study illustrate that GDP can increase the financial sector development. It could therefore, be said that these 12 West African countries should pay more attention in the GDP for a continuous economic growth. Policies which may improve the increase of GDP should be made and follow appropriately. The viability in the financial sector accelerate the economic growth development.

\section{Exchange Rate}

Based on the analysis of the data in this study the results of the analysis show that the level of Exchange Rate has a significant positive effect on the financial sector development with a probability value of $0.0008<0.05$. The results of this study illustrate that Exchange Rate can also increase the financial sector development. We can therefore, say that the Exchange Rate in these countries contribute immensely to the financial sector development sector. The proposed plan by the ECOWAS heads of state to launch a single currency that is to be use by all the sixteen countries in West Africa is a very good move.

\section{Trade Openness}

Based on the analysis of the data in this study the results of the analysis show that the level of Trade Openness has a significant positive effect on the financial sector with a probability value of $0.0009<0.05$. The results of this study illustrate that TO can increase the financial sector development. The results of this study are also consistent with the proposed hypothesis, stating that TO have a positive relationship with the financial development in the 12 West African countries in 2004-2013. A proper TO can accelerate the economic growth and open the financial development sector through foreign direct investment. The main source of foreign exchange is from TO, therefore the trade openness is a big contributing factor of any country economic growth development. According to Ngongang (2015), the result of his findings reveals that, trade openness of SSA countries has a positive and insignificant impact on economic growth. 


\section{Interest Rate}

Based on the analysis of the data in this study, the result shows that the level of Interest Rate does not significantly influences the financial sector development in a positive direction and the probability value is $0.1505>0.05$. The results of this study illustrate that Interest Rate can reduce the financial sector development. Therefore, the West African region should set policies that would create ways to increase the level of real interest rates. By so doing, it would add to contribute to the economic growth development especially in the financial sector.

\section{Conclusion}

This article aimed to determine the financial sector performance in 12 West African countries. In conclusion, there is evidence that financial sector performance positively impacted the selected 12 West African countries' economic growth. Three variables indicator of financial sector performance (exchange rate, gross domestic product, and trade openness) positively influenced economic growth, while one (interest rate) indicator negatively influenced economic growth.

Using financial development data, we confirm our previous findings. Financial sector explains the growth of finance beyond the rates predicted by the internal resources and short-term development. This is consistent with both the market and the bank-based view. The share of financial sector performance for external financing is higher in West African countries with higher levels of financial sector development, which is consistent with the financial-services view. Furthermore, we find that West African countries are more likely to grow at rates that require external finance in which the contracting environment favours financial sector development.

\section{References}

Akinlo, A. E. and Egbetunde, T. (2010). Financial Development and Economic Growth: The Experience of 10 Sub-Saharan African Countries Revisited. Review of Finance and Banking, 2(1), 17-28. Retrieved from https:// econpapers.repec.org/scripts/redir.pf?u $=$ http $\% 3 \mathrm{~A} \% 2 \mathrm{~F} \% 2 \mathrm{Fwww} . \mathrm{rfb} . \mathrm{ase} . \mathrm{ro} \%$ 2Farticole\%2FA2-Akinlo.pdf;h=repec:rfb:journl:v:02:v:2010:i:1:p:017-028

Balassa, B. (1990). Financial Liberalization in Developing Countries. Studies in Comparative International Development, 25(4), 56-70. https://doi.org/10.1007/bf02806290

Beck, M. W., Brumbaugh, R. D., Airoldi, L., Carranza, A., Coen, L. D., Crawford, C., Defeo, O., Edgar, G. J., Hancock, B., Kay, M. C., Lenihan, H. S., Luckenbach, M. W., Toropova, C. L., Zhang, G., \& Guo, X. (2011). Oyster Reefs at Risk and Recommendations for Conservation, Restoration, and Management. BioScience, 61(2), 107-116. http://dx.doi.org/10.1525/bio.2011.61.2.5

Beck, T., Demirguc-Kunt, A., Levine, R., \& Maksimovic, V. (2000). Financial Structure and Economic Development: Firm, Industry, and Country Evidence. Policy Research Working 
Paper;No. 2423. World Bank, Washington, DC. Retrieved from http://hdl.handle.net/10986/19809

Cecchetti, S. G., \& Kharroubi, E. (2012). Reassessing the impact of finance on growth. BIS Working Paper, 1-21.

de Soto, J. H. (2006). Money, Bank Credit, and Economic Cycles. Ludwig von Mises Institute, Alabama.

Didier, T., \& Schmukler, S. L. (2013) Financial Development in Latin America and the Caribbean: Stylized Facts and the Road Ahead. Emerging Issues in Financial Development: Lessons from Latin America. 14(4), 25-89. https://doi.org/10.1596/978-0-8213-9828$\underline{9}$ ch1

Ivashina, V., \& Scharfstein, D. (2010). Bank lending during the financial crisis of 2008. Journal of Financial Economics. 97(3), 319-338. https://doi.org/10.1016/i.jifineco.2009.12.001

King, R. G. \& Levine, R. (1993). Finance and Growth: Theory, Evidence, and Mechanisms. The Quarterly Journal of Economics, 108(3), 107. https://doi.org/10.2307/2118406

Levine, R. (1997). Financial Development and Economic Growth: Views and Agenda. Journal of Economic Literature, 35(2), 688-726. https://doi.org/10.1596/1813-9450-1678

Obradovic, S., Sapic, S., Furtula, S., \& Lojanica, N. (2017). Linkages between Inflation and Economic Growth in Serbia: An ARDL Bounds Testing Approach. Engineering Economics, 28(4), 401-410. https://doi.org/10.5755/i01.ee.28.4.14003

Shan, J., \& Qi, J. (2006). Does Financial Development 'Lead' Economic Growth? The Case of China. Annals of Economics and Finance, 7, 197-216. https://doi.org/10.1080/00036840500118762

Soltani, R., Haghighat, A., Fanaei, M., \& Asghari, M. (2014). Evaluation of the effect of green tea extract on the prevention of gingival bleeding after posterior mandibular teeth extraction: A randomized controlled trial. Evidence-based Complementary and Alternative Medicine, 1-4. https://doi.org/10.1155/2014/857651

Sosa, M. E., \& Marle, F. (2013). Assembling creative teams in new product development using creative team familiarity. Journal of Mechanical Design, Transactions of the ASME, 135(8), 1-13. https://doi.org/10.1115/1.4024763

Vazakidis, A., \& Adamopoulos, A. (2009). Stock market development and economic growth. American Journal of Applied Sciences, 6(11), 1933-1941.

https://doi.org/10.3844/ajassp.2009.1932.1940 